Marganda et al./ The Effect of Toluene Exposure on Central Nervous Disorder

\title{
The Effect of Toluene Exposure on Central Nervous Disorder among Printing Workers
}

\author{
Samuel Marganda, Taufik Ashar, Nurmaini \\ Department of Environmental Health, Faculty of Public Health, Universitas Sumatera
}

\begin{abstract}
Background: The use of toluene in printing dominates the use of metal chemicals. Toluene is used in $75 \%$ of printing work activities. Accumulation of toluene concentrations in printing can cause health problems to workers. The purpose of this study was to analyze the effect of toluene exposure on central nervous system disorders in printing industry workers.

Subjects and Method: This study was cross sectional in the printing industry in Medan, North Sumatra. The population consists of 50 people with consecutive sampling technique sampling. Data on subjective symptoms of central nervous system disorders were measured by the German version of the Q18 questionnaire. The data were analyzed using multiple logistic regression tests.

Results: Subjective symptoms of central nervous system disorders increased with tenure $\geq 2$ years $(\mathrm{OR}=4.19 ; \mathrm{p}=0.018)$ and smoking $(\mathrm{OR}=8.91 ; \mathrm{p}=0.001)$. Subjective symptoms of central nervous system disorders decreased with age $\leq 30$ years $(\mathrm{OR}=0.17 ; \mathrm{p}=0.004)$, female $\operatorname{sex}(\mathrm{OR}=0.50 ; \mathrm{p}=0.002)$.

Conclusions: The most dominant variable affecting the subjective symptoms of central nervous system disorders is the smoking habit variable with a probability value of 0.92 or $92 \%$.
\end{abstract}

Keywords: subjective symptoms, central nervous system disorders, workers, printing industry

\section{Correspondence:}

Samuel Marganda. Department of Environmental Health, Faculty of Public Health, Universitas Sumatera Utara, Medan, North Sumatera. Email: samuelmarganda@yahoo.co.id.

Mobile: 085362985340.

\section{BACKGROUND}

Organic solvents are widely used in printing activities, in addition to lead, copper, and other metals. The organic solvent used is toluene. Toluene $\left(\mathrm{C}_{6} \mathrm{H}_{5} \mathrm{CH}_{3}\right)$ is a non-corrosive folateil liquid that has a smell like benzene. Workers who use toluene as a solvent cause health problems, such as dizziness, vertigo, eye irritation, skin irritation, respiratory, liver, kidney, and central nervous system disorders (Agency for Toxic Substances and Disease Registry, 2000). The use of toluene in printing dominates the use of metal chemicals. Toluene is used in $75 \%$ of printing work activities. The biggest use of toluene is in automatic cleaning, which is around 50-200 ppm (Svendsen and Rognes, 2000). Toluene is declared safe for the environment and health if it does not cross the threshold. The toluene threshold in the environment is around $50 \mathrm{ppm}$ (American Conference of Industrial Hygienists, 2005). According to Ministerial Regulation No. PER.13/MEN/X/2011, the toluene threshold value is $188 \mathrm{mg} / \mathrm{m}^{3}$.

Nervous disorders due to toluene exposure consist of two types, neurotoxic and neuropathy. The prevalence of neuropathy due to exposure to organic solvents 
is greater than neurotoxic. Ropper (2000) defines neuropathy as a clinical symptom due to peripheral nerve abnormalities, extensive non-inflammatory regeneration with symptoms of motor weakness, sensory disorders, autonomic nerves, and weakening of tendon reflexes.

Neuropathy due to toluene exposure that often arises is peripheral nerve neuropathy. Collective peripheral nerve neuropathy is available in $2.4 \%$ of the world population (Martyn, 1998). Neuropathic pain is defined as sensory pain or discomfort due to lesions or diseases associated with the somato-sensory nervous system (International Association for the Study of Pain, 2011). The prevalence of neuropathy pain is higher than the prevalence of peripheral nerve neuropathy, which is about $3 \%$ of the world's population (Gilron et al., 2006). The presence of peripheral nerve neuropathy and its manifestations (neuropathic pain) in workers disrupts work activities. Offset work is less than optimal. This is compounded by exposure to organic solvents which are the cause of neuropathy.

In Germany, diseases due to chronic exposure to solvents associated with neurotoxic chemicals have been included in the list of occupational diseases since 1997. Because many subjective complaints indicate this disease, early recognition is very important, especially in the workplace with exposure to neurotoxic, sensitive, specific chemicals and practical screening equipment is needed.

Ihrig et al. (2001) concluded that the German version of the Q18 questionnaire was a sensitive and reliable screening questionnaire for complaints related to solvent exposure, but not reliable enough for individual diagnosis. The researcher also distinguished the questionnaire cutoff point by sex for both men and women. For men, the recommended cut-off point for five or more complaints on the German version of the Q18 questionnaire, while for women, the cut-off point for six or more complaints is recommended as the starting point for further evaluation (Ihrig, et al, 2001). After conducting the initial survey, no workers used masks during work. Of the 6 sample points studied, most experienced several health complaints such as frequent dizziness, sore eyes, disturbances in breathing, and hallucinations.

Based on the description above, the researchers want to conduct a study on the relationship of toluent exposure to subjective symptoms of central nervous system disorders in printing workers in Medan.

\section{SUBJECT AND METHOD}

This was an analytic observational study with a cross sectional design. The study was conducted in 6 printing industries in Medan. An examination of ambient air samples for toluene measurements was carried out at the Medan K3 Hall Laboratory.

A sample of 50 workers was selected by consecutive sampling. Data on subjective symptoms of central nervous system disorders were measured using the German version of the Q18 questionnaire.

\begin{tabular}{l}
\hline RESULTS \\
\hline 1. Sample Characteristics \\
Table 1 showed sample characteristics. \\
Table 1 showed that most of the study \\
subjects were at age <30 years $(62 \%)$ and \\
male gender (76\%). As many as 29 \\
workers had tenure less than 2 years. As
\end{tabular}


many as $70 \%$ workers had toluene exposure more than 8 hours/day.

As many as 17 workers (34\%) were smokers. A worker (2\%) alcohol consumer

Table 1. Sample Characteristics

\begin{tabular}{|c|c|c|}
\hline Variables & $\mathbf{n}=\mathbf{5 0}$ & $\%$ \\
\hline \multicolumn{3}{|l|}{ Age } \\
\hline$<30$ years & 31 & 62 \\
\hline$\geq 30$ years & 19 & 38 \\
\hline \multicolumn{3}{|l|}{ Gender } \\
\hline Male & 38 & 76 \\
\hline Female & 12 & 24 \\
\hline \multicolumn{3}{|l|}{ Tenure } \\
\hline$\leq 2$ years & 29 & 58 \\
\hline$>2$ years & 21 & 42 \\
\hline \multicolumn{3}{|l|}{ History of Disease } \\
\hline No & 16 & 32 \\
\hline Yes & 34 & 68 \\
\hline \multicolumn{3}{|l|}{ Smoking } \\
\hline Yes & 17 & 34 \\
\hline No & 33 & 66 \\
\hline \multicolumn{3}{|l|}{ Alcohol drink consumption } \\
\hline Yes & 1 & 2 \\
\hline No & 49 & 98 \\
\hline \multicolumn{3}{|l|}{ Drugs use } \\
\hline Yes & 2 & 4 \\
\hline No & 48 & 96 \\
\hline \multicolumn{3}{|l|}{ PPE use behavior } \\
\hline Yes & 43 & 86 \\
\hline No & 7 & 14 \\
\hline \multicolumn{3}{|l|}{ Exposure time } \\
\hline$>8$ hours & 35 & 70 \\
\hline$\leq 8$ hours & 15 & 30 \\
\hline
\end{tabular}

Table 2.The Toluent level

\begin{tabular}{ccccccc}
\hline Variable & Mean & SD & Min. & Max. & CI (95\%) & p \\
\hline Toluene level & 6.97 & 13.04 & 0.019 & 34.46 & $3.27-10.68$ & 0.001 \\
\hline
\end{tabular}

\section{Toluene level}

Table 2 described the toluene level in printing industry in Medan. Table 2 showed that the average toluene level was $6.97 \mathrm{mg} / \mathrm{m}^{3}$ with the lowest level was $0.019 \mathrm{mg} / \mathrm{m}^{3}$ and the highest level was $34.46 \mathrm{mg} / \mathrm{m}^{3}$. and as many as two workers (4\%) consumed drugs. As for the use of PPE, there were 43 respondents (86\%) who did not use PPE. 
Indonesian Journal of Medicine (2018), 3(3): 125-133

https://doi.org/10.26911/theijmed.2018.03.03.01

Table 3. Frequency Distribution of Subjective Symptoms of Central Nervous System Disorders among Printing Workers

\begin{tabular}{ccc}
\hline $\begin{array}{c}\text { Subjective Symptoms of Central } \\
\text { Nervous System Disorders }\end{array}$ & N & \% \\
\hline No & 31 & 62 \\
Yes & 19 & 38 \\
\hline
\end{tabular}

Table 4. The Results of Chi Square Test

\begin{tabular}{|c|c|c|c|c|c|c|c|}
\hline \multirow{3}{*}{ Independent Variables } & \multicolumn{4}{|c|}{$\begin{array}{c}\text { Symptoms of CNS } \\
\text { Disorders }\end{array}$} & \multirow{3}{*}{$\mathbf{O R}$} & \multirow{3}{*}{ CI 95\% } & \multirow{3}{*}{$\mathbf{p}$} \\
\hline & \multicolumn{2}{|c|}{ Positive } & \multicolumn{2}{|c|}{ Negative } & & & \\
\hline & $\mathbf{n}$ & $\%$ & $\mathbf{n}$ & $\%$ & & & \\
\hline \multicolumn{8}{|l|}{ Age } \\
\hline$\leq 30$ years old & 7 & 22.6 & 24 & 77.43 & 0.17 & 0.05 to 0.60 & 0.004 \\
\hline >3oyears old & 12 & 63.1 & 7 & 6.9 & & & \\
\hline \multicolumn{8}{|l|}{ Gender } \\
\hline Male & 19 & 50 & 19 & 50 & 0.50 & 0.36 to 0.69 & 0.002 \\
\hline Female & 0 & 0 & 12 & 100 & & & \\
\hline \multicolumn{8}{|l|}{ Tenure } \\
\hline$>2$ years & 12 & 57.1 & 9 & 42.9 & 4.19 & 1.25 to 14.09 & 0.018 \\
\hline $\begin{array}{l}\leq 2 \text { years } \\
\text { Smoking }\end{array}$ & 7 & 24.1 & 22 & $75 \cdot 9$ & & & \\
\hline Smoke & 12 & 70.6 & 5 & 29.4 & 8.91 & 2.34 to 33.91 & 0.001 \\
\hline Did not smoke & 7 & 21.2 & 26 & 78.8 & & & \\
\hline \multicolumn{8}{|l|}{ Alcohol Consumption } \\
\hline Yes & $\mathrm{O}$ & o & 1 & 100 & 1.63 & 1.31 to 2.04 & 0.429 \\
\hline No & 19 & 38.8 & 30 & 61.2 & & & \\
\hline \multicolumn{8}{|l|}{$\begin{array}{l}\text { Length of toluene } \\
\text { exposure }\end{array}$} \\
\hline$>8$ hours/day & 15 & 42.9 & 20 & 57.1 & 2.06 & 0.55 to 7.77 & 0.280 \\
\hline$\leq 8$ hours/day & 4 & 26.7 & 11 & $73 \cdot 3$ & & & \\
\hline \multicolumn{8}{|l|}{ Drug Consumption } \\
\hline Yes & o & o & 2 & 100 & 1.66 & 1.32 to 2.08 & 0.258 \\
\hline No & 19 & 39.6 & 29 & 60.4 & & & \\
\hline \multicolumn{8}{|l|}{ PPE use } \\
\hline Yes & 1 & 14.3 & 6 & $85 \cdot 7$ & $4 \cdot 32$ & 0.48 to 39.07 & 0.163 \\
\hline No & 18 & 41.9 & 25 & 58.1 & & & \\
\hline \multicolumn{8}{|l|}{ History of Disease } \\
\hline Yes & 13 & 38.2 & 21 & 61.8 & 1.03 & 0.30 to 3.52 & 0.960 \\
\hline No & 6 & 37.5 & 10 & 62.5 & & & \\
\hline
\end{tabular}

\section{Bivariate analysis}

Table 4 showed the result of bivariate analysis using Chi square test. Table 4 showed that age $<30$ years old $(\mathrm{OR}=0.17$; $95 \% \mathrm{CI}=0.05$ to $0.60 ; \mathrm{p}=0.004)$ and gender $(\mathrm{OR}=0.50 ; 95 \% \mathrm{CI}=0.36$ to 0.69 ; $\mathrm{p}=0.002)$ decreased the risk of subjective symptoms of central nervous system disorders among printing workers. These relationships were statistically significant. Tenure $>2$ years $(\mathrm{OR}=4.19 ; 95 \%$ $\mathrm{CI}=1.25$ to $14.09 ; \mathrm{p}=0.018$ ) and smoking 
$(\mathrm{OR}=8.91 ; 95 \% \mathrm{CI}=2.34$ to $33.91 ; \mathrm{p}=$ o.001) increased the risk of subjective symptoms of central nervous system disorders among printing workers.

Alcohol consumption $(\mathrm{OR}=1.63$; 95\% $\mathrm{CI}=1.31$ to $2.04 ; \mathrm{p}=0.429)$, toluene exposure $>8$ hours/day $(\mathrm{OR}=2.06 ; 95 \%$ $\mathrm{CI}=0.55$ to $7.77 ; \mathrm{p}=0.280$ ), drug consumption $(\mathrm{OR}=1.66 ; 95 \% \mathrm{CI}=1.32$ to 2.08; $\mathrm{p}=0.258)$, did not use PPE properly $(\mathrm{OR}=4.32 ; 95 \% \mathrm{CI}=0.48$ to $39.07 ; \mathrm{p}=$ $0.163)$, and had history of disease (OR= 1.03; 95\% $\mathrm{CI}=0.30$ to $3.52 ; \mathrm{p}=0.960$ ) increased the risk of subjective symptoms of central nervous system disorders among printing workers, but these rela- tionships were statistically nonsignificant.

\section{Multivariate analysis}

Table 5 showed the results of multivariate analysis. Table 5 showed that smoking was positively and statistically significant associated with subjective symptoms of central nervous system disorders among printing workers $(b=5.18 ; p=0.042)$.

Age $<30$ years old $(b=0.27 ; p=$ 0.163), tenure $(b=1.41 ; p=0.692)$, PPE use $(b=0.56 ; p=0.737)$, and length of toluene exposure $<8$ hours/day $(b=0.32$; $\mathrm{p}=0.317$ ) were positively and statistically non-significant associated with subjective symptoms of central nervous system disorders among printing workers.

Table 5. The effects of age, gender, tenure, smoking, PPE use, and toluene level on subjective symptoms of central nervous system disorders

\begin{tabular}{lcc}
\hline Independent Variables & $\mathbf{b}$ & $\mathbf{p}$ \\
\hline Age & 0.27 & 0.163 \\
Gender & 4.35 & 0.999 \\
Tenure & 1.41 & 0.692 \\
Smoking & 5.18 & 0.042 \\
PPE use & 0.56 & 0.737 \\
Length of toluene exposure $<8$ hours/day & 0.32 & 0.317 \\
\hline
\end{tabular}

\section{DISCUSSIONS}

Based on the results of the study by using the German version of the Q18 questionnaire, it was found that there were 19 people who experienced subjective symptoms of central nervous system disorders.

1. The relationship between age and the risk of subjective symptoms of central nervous system disorders among printing workers

The results of this study showed that age $<30$ years old was positively but statistically non-significant associated with subjective symptoms of central nervous system disorders among printing workers
Age was an important variable in the case of subjective symptoms of central nervous system disorders. The ability of the organs of the body would decrease naturally with increasing age. A study by Gamble (2000) stated that age 20-24 years old showed an increase in the incidence of neurobehavioral disorders due to solvent exposure and continued to be constant until the age of 40 years old, then subsequently decreased.

A study by Rusdy (2012) showed a negative relationship between age and neurotoxic incident $(\mathrm{r}=-0.01)$, but it was statistically non-significant $(\mathrm{p}>0.050)$. This was due to the majority of the study 
subjects aged 30-40 years old and neurotoxic symptoms that were felt to be subjective, most of them did not understand the associated neurotoxic symptoms.

\section{The relationship between} smoking and the risk of subjective symptoms of central nervous system disorders among printing workers

The results of this study showed that smoking was positively and statistically significant associated with subjective symptoms of central nervous system disorders among printing workers.

The results of this study were in line with a study by Ovina (2013) which reported that there was a significant relationship between smoking habits and the prevalence of non-hemorrhagic stroke in the Neurology Poly of Raden Mattaher Hospital.

\section{REFERENCES}

Agency for Toxic Substances and Disease Registry (2000). Toxicological profile for toluene. Georgia. http://www.atsdr.cdc.gov/toxprofiles.

Agency for Toxic Substances and Disease Registry (2001), Toluene Toxicity, Georgia http://www.atsdr.cdc.gov/csem/toluene/index.html

Agustina U (2013). Hubungan toluen dengan kadar hippurat urin dan keluhan SSP pada pekerja bengkel, FKM, UNAIR

American Conference of Govermental Industrial Hygienists (1995). Documentation of The Threshold Limit Values (TLVs) and Biological Exposure Indices (BEIs), Washington.

American Conference of Governmental Industrial Hygienist (ACGIH) (2005), TLV® and BEI $®$ docu- mentation of the threshold limit values for chemical substances and physical agents and biological exposure indices, ACGIH, USA.

American Conference of Governmental Industrial Hygienist (ACGIH) (2008), TLV $\AA$ and BEI $\AA$ Based on the Documentation of the Threshold Limit Values for Chemical Substances and Physical Agents and Biological Exposure Indices, ACGIH, USA

Azari MR, Konjin ZN, Pours ZFS, Seyedi MD (2012). Occupational Exposure of Petroleum Depot Workers to BTX Compounds, The International Journal of Occupational Environmental Medicine (IJOEM), 3: 9-44.

Batticaca F (2008). Asuhan keperawatan pada klien gangguan sistem persarafan. Jakarta: SalembaMedika

BPOM RI (2001). Aspek fundamental kajian dan pengendalian risiko bahan kimia. Direktorat Pengawasan Produk dan Bahan Berbahaya. Deputi Bidang Pengawasan Keamanan Pangan dan Bahan Berbahaya, Jakarta.

Chang CJ, Chen CJ, Lien CH, Sung FC, (2006). Hearing loss in workers exposed to toluene and noise. Environmental Health Perspectives. 114(8).

Darwati (2004). Analisis gejala neuropsikologis pada pengguna toluen di unit TBK (Aircraft Cabin Base Maintenance) PT. Garuda Meintenance Facility Aero Asia Cengkareng, Depok.

Darmono (2011), Drug on the central nervous system, Bogor.

Depkes RI, (2008), Profil Kesehatan Indonesia, Jakarta.

Draper THJ, Bamiou DE (2009). Auditory neuropathy in a patient exposed to 
xylene: case report. The Journal of Laryngology \& Otology, 123:462465 .

Ekaputri S (2012). Hubungan paparan toluen dengan kadar asam hipurat urine pekerja pengecetan mobil (studi pada bengkel mobil informal di Karasak, Kota Bandung). FakultasTeknikSipildanLingkungan. ITB

Environmental Protection Agency (1991), Human health evaluation manual supplemental guidance, Standart Default Exposure Factor. Washington DC.

Environmental Protection Agency (2005), Integrated Risk Information System: Toluene, http://www.epa.gov/NCEA/iris/

EPA, (2003), Toxicological Review of Xylenes, In Support of Summary Information on the Integrated Risk Information System (IRIS), U.S. Environmental Protection Agency Washington, D.C

Gamble JF (2000).Low-level hydrocarbon solvent exposure and neurobehavioural effects.Occup Med, vol 50:81-102, London

George D.Clayton\& Florence D. Clayton, (1994), Patty's Industrial Hygiene \& Toxicology. 4th edisi vol. 11 Part B.A Willey_Interscience Publication. John Willey \& Sons Inc

Gilron I, Watson CPN, Cahill CM, Moulin DE (2006). Neuropathic pain: a practical guide for the clinician. Canadian Medical Association Journal, 175:265-275. doi: 10.1503/cmaj.060146.

Huang CC (2008). Polyneuropathy Induced by $\mathrm{n}$-Hexane Intoxication in Taiwan. ActaNeurol Taiwan, 17 (1):3-1
Ihrig A, Triebig G, Dietz MC (2001). Evaluation of a modified German version of the Q16 Questionnaire for neurotoxic symptoms in workers exposed to solvents, Germany.

International Association for the Study of Pain (2011).IASP pain terminology. Washington, DC: International Association for the Study of Pain. Retrieved from www.iasppain.org/AM/Template.cfm.Section.Pain_Def initions.

International Programme on Chemical Safety (IPCS), (2000). Environmental Health Criteria 214 Human Exposure Assessment, IOMC,WHO, Geneva

International Programme on Chemical Safety (IPCS), (2000), Air Quality Guidelines Toluene, WHO, Geneva, http://www.euro.who.intdocumenta iq514toluen.pdf

Kolluru RV, Bartell SM, Pitblado RM and Stricoff RS, (1996), Risk Assessment and Management Handbook: For Environmental Health and Safety Professionals, New York, McGrawHill

La Dou J (2004). Occupational and Environmental Medicine, San Francico.

Lemeshow S (1997). Besar Sampel Dalam Penelitian Kesehatan, GadjahMada University Press, Yogyakarta.

Lestari F, Kurniawidjaja LM, Tejamaya M (2008). Laporan akhir kajian risiko kesehatan kerja pada pekerja yang terpajan benzena, toluene dan xylena (BTX) Departemen Laboratorium K3 FKM UI dan Direktorat Bina Kesehatan Kerja Depkes RI.

Louvar FL and Louvar BD (1998). Health and environmental risk analysis: Fundamental with application, 
Volume 2, New Jersey, Prentice Hall PTR

Lubman DI, Yucel M, Lawrence AJ (2008). Inhalant abuse among adolescents: neurobiological considerations. British Journal of Pharmacology, 154:316-326.

Mansyur M (2007). Manajemen Risiko Kesehatan, Majalah Kedokteran Indonesia, 57(10).

Martyn C, Hughes RAC (1998). Peripheral neuropathies. London: BMJ

Chen MS, Chan A (1999).China's 'Market Economics in Command': Footwear Workers' Health in Jeopardy. International Journal of HealthServices, 29(4): 793-811.

Mukono (2005). Toksikologi Lingkungan. Surabaya: Airlangga University Press.

Newman MJ (2012). Classification of diseases and conditions affecting the periodontium, In: Newman, Takei, Klokkerold, Carranza. Carranza's Clinical Periodontology. 11 th Ed, 34-54.

Nusanti S (2007). Efek pajanan toluene pada tingkat apoptosis dan fungsi mitokondria self otoreseptor serta retinal pigment epithelium tikus, FK UI, Jakarta.

Ovina Y (2013). Hubungan Pola Makan, Olahraga dan Merokok terhadap Prevalensi Penyakit Stroke Non Hemorgik di PoliSaraf RSUD Raden Mattaher Jambi Tahun 2013. Jambi Medical Journal. Jambi

Palar H (2008). Pencemaran dan Toksikologi Logam Berat. Jakarta: PT. Rineka Cipta.

Palencia G, Hernandez-Pedro N, Saavedra-Perez D, Pena-Curiel O, Plata AO, Ordonez G, Flores-Estrada D,
Sotelo J,Arrieta O (2014). Retinoic acid reduces solvent-induced neuropathy and promotes neural regeneration in mice. J. Neurosci. Res., 92:1062-1070. doi: 10.1002/jnr.23376

Peraturan Menteri Tenaga Kerja dan Transmigrasi Nomor Per. 13/ Men/ $\mathrm{X} / 2011$ Tahun 2011 tentang nilai ambang batas faktor fisika dan faktor kimia di tempat kerja.

Pratamasari F (2015). Kejadian Neuropati Saraf Tepi pada Pekerja Percetakan Offset yang Terpajan Toluen Inhalasi, Gadjah Mada University Press, Yogyakarta.

Rahman A (2010). Prinsip-prinsip dasar dan metode analisis risiko kesehatan lingkungan dalam bahan ajar pelatihan teknik dan manajemen analisis dampak kesehatan lingkungan bagi petugas kesehatan, balai besar teknik kesehatan lingkungan dan pemberantasan penyakit menular Yogyakarta.

Ropper AH, Samuels MA (2000).Disease of peripheral nerve. Adams \&Victor's Principles of Neurology (7 th Edition). New York: The McGraw Hill

Rusdy MDR (2012). Analisis gejala neurotoksik akibat pajanan pelarut organik xylene pada pekerja pembuatan cat di PT X [Thesis]. Depok: Universitas Indonesia;.

Sentra Informasi Keracunan Nasional (SiKerNas) Pusat Informasi Obat dan Makanan, Badan POM RITahun 2012

Smeltzer CS, Bare GB (2002). Buku Ajar KeperawatanMedikal-Baedah, Jakarta : EGC

Sophianita (2003), Hubungan antara Kadar Asam Hipurat Urin Akibat 
Pajanan Toluen dengan Efek Kesehatan Akut pada Tenaga Kerja Percetakan "X", FK UI, Jakarta.

Suma'mur (2009). Higiene Perusahaan dan Keselamatan Kerja. Jakarta: CV SagungSeto.

Svendsen, K, Rognes, K, 2000, Exposure To Organic Solvents in The Offset Printing Industry, Norway, Annals of Occupational Hygiene 44(2):11924, April 2000.

Tarwoto, Wartonah, Suryati, E. S, (2007), Keperawatan Medikal Bedah Gangguan Sistem Persyarafan, Jakarta: EGC.

Toluene Tox Guide-Agency for Toxic Substances and Disease Registry. https://www.atsdr.cdc.gov/toxguide s/toxguide-56.pdf

Widada B (2000). Pengenalan Alat Kromatografi Gas, AlatAnalis, ISSN 1852-4777, URANIA,No.23-24

Wulandari D (2017). Hubungan pajanan senyawa benzena dengan kadar trans-trans muconic acid dalam urin pengrajin sepatu di kelurahan Tambak Oso Wilangun Surabaya, Universitas Airlangga.

Yuksel G, Karlikaya G, Tutkavul K, Yildirim B, Orken C, Tireli H (2007). Clinical and electrodiagnostic findings of $\mathrm{n}$-hexane neuropathy. $\mathrm{J}$ NeurolSci [Turk]. 24:219-225 